\title{
The vertical slip rate of the Sertengshan piedmont fault, Inner Mongolia, China
}

\author{
Hao Zhang ${ }^{\mathrm{a}}$, Zhongtai He ${ }^{\mathrm{a}, *}$, Baoqi Ma ${ }^{\mathrm{a}}$, Jianyu Long ${ }^{\mathrm{a}}$, Kuan Liang ${ }^{\mathrm{a}}$, Jinyan Wang ${ }^{\mathrm{b}}$ \\ a Key Laboratory of Crustal Dynamics, Institute of Crustal Dynamics, China Earthquake Administration, Beijing, China \\ b Institute of Earthquake Engineering for Jiangsu Province, Nanjing, China
}

\section{A R T I C L E I N F O}

\section{Keywords:}

Vertical slip rate

Sertengshan piedmont fault

Terrace

Geological borehole

\begin{abstract}
A B S T R A C T
The vertical slip rate of a normal fault is one of the most important parameters for evaluating its level of activity. The Sertengshan piedmont fault has been studied since the 1980s, but its absolute vertical slip rate has not been determined. In this paper, we calculate the displacements of the fault by measuring the heights of piedmont terraces on the footwall and the stratigraphic depths of marker strata in the hanging wall. We then calculate the vertical slip rate of the fault based on the displacements and ages of the marker strata. We selected nine sites uniformly along the fault to study the vertical slip rates of the fault. The results show that the elevations of terraces T3 and T1 are approximately $1060 \mathrm{~m}$ and $1043 \mathrm{~m}$, respectively. The geological boreholes in the basin adjacent to the nine study sites reveal that the elevation of the bottom of the Holocene series is between 1017 and $1035 \mathrm{~m}$ and that the elevation of the top of the lacustrine strata is between 925 and $1009 \mathrm{~m}$. The data from the terraces and boreholes also show that the top of the lacustrine strata is approximately 65 ka old. The vertical slip rates are calculated at $0.74-1.81 \mathrm{~mm} / \mathrm{a}$ since $65 \mathrm{ka}$ and $0.86-2.28 \mathrm{~mm} / \mathrm{a}$ since the Holocene. The slip rate is the highest along the Wujiahe segment and is lower to the west and east. Based on the findings of a previous study on the fault system along the northern margin of the Hetao graben basin, the vertical slip rates of the Daqingshan and Langshan faults are higher than those of the Sertengshan and Wulashan faults, and the strikeslip rates of these four northern Hetao graben basin faults are low. These results agree with the vertical slip components of the principal stress field on the faults. The results of our analysis indicate that the Langshankou, Wujiahe, and Wubulangkou areas and the eastern end of the Sertengshan fault are at high risk of experiencing earthquakes in the future.
\end{abstract}

\section{Introduction}

The Sertengshan piedmont fault in Inner Mongolia, northern China, is approximately $185 \mathrm{~km}$ long and extends E-W from Dongwugai through Langshankou and Wujiahe to Wubulangkou, where it turns to $300^{\circ}$ and proceeds through Dongfengcun, Dashetai, and Wulancun to Tailiang. This E-W- to NW-SE-striking fault dips southward in the form of a typical dip-slip normal fault. Together with the Langshan piedmont fault (LPF; Fig. 1) to the west and the Wulashan and Daqingshan piedmont faults (WPF and DPF, respectively; Fig. 1) to the east, it is part of the northern fracture zone of the Hetao graben basin, which controlled the formation and development of the basin (Fig. 1). Many organizations and researchers have studied the active tectonic landforms and kinematic characteristics of the Sertengshan piedmont fault since the 1980s. The maximum vertical slip rates of the footwall of the Sertengshan piedmont fault were estimated at $3.6 \mathrm{~mm} /$ a since the late
Pleistocene and $2.2 \mathrm{~mm} / \mathrm{a}$ during the Holocene.* Yang et al. (2002, 2003) obtained vertical slip rates for the middle segment of the fault of $0.48-1.83 \mathrm{~mm} / \mathrm{a}$ since the late Pleistocene and $0.56-0.89 \mathrm{~mm} / \mathrm{a}$ during the Holocene based on geological boreholes, terrace heights and thermoluminescence dating data. Chen et al. (2003b) studied the eastern segment of the fault and obtained a vertical slip rate of approximately $0.20 \mathrm{~mm} / \mathrm{a}$ since the late Pleistocene based on the height of a terrace (T2) and thermoluminescence dating data. Li (2006) obtained tectonic uplift rates for the footwall of $0.42-1.00 \mathrm{~mm} / \mathrm{a}$ along the middle segment of the fault and $1.08-2.13 \mathrm{~mm} / \mathrm{a}$ along the eastern segment of the fault since $24 \mathrm{ka}$ based on the history of the Jilantai-Hetao Megalake and the terrace characteristics of the northern margin of the Hetao basin. Numerous geological boreholes have been drilled and many samples have been dated to study the sedimentary formations of the Hetao basin and the evolutionary history of the Jilantai-Hetao Megalake (Chen et al., 2008a,

\footnotetext{
* Corresponding author.

E-mail address: hezhongtai@126.com (Z. He).

* Institute of Crustal Dynamics, China Earthquake Administration, 1995. The 1:50,000 geological mapping and comprehensive research of the Sertengshan Piedmont Fault.
} 


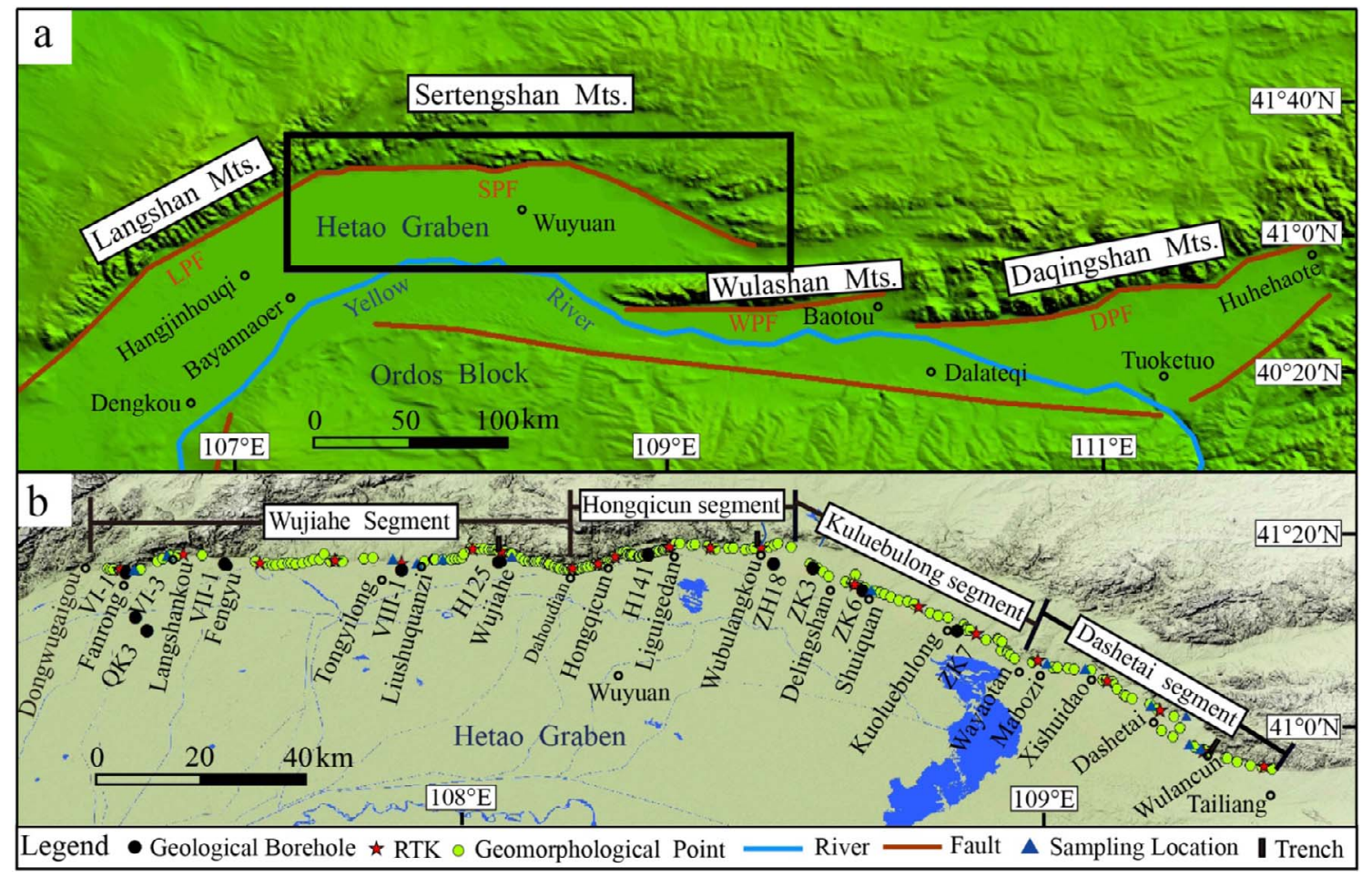

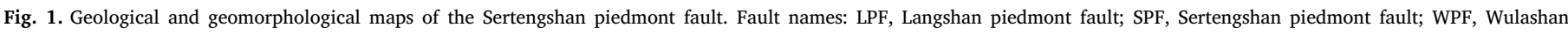
piedmont fault; DPF, Daqingshan piedmont fault.

\section{8b; Liu et al., 2014).}

Most previous studies have used terrace displacement data and thermoluminescence dating data from the footwalls of faults to calculate the tectonic uplift rates of the footwalls. However, we believe that the tectonic uplift rate is much lower than the actual vertical slip rate of the fault and that the thermoluminescence dating data are unreliable.

We determined the terrace heights along the Sertengshan piedmont fault using a laser distance meter and acquired terrain data of typical structural landforms using the real-time kinematic (RTK) measuring method. We also collected geological borehole data on the basin stratigraphy in the hanging wall. Using these data, we obtained the absolute vertical displacement of the fault. We performed optically stimulated luminescence (OSL) dating of samples from the terraces on the footwall and identified the stratigraphic ages of the units in the geological boreholes in the hanging wall to calculate the absolute vertical slip rates of the fault. We combine the vertical slip rates and the tectonic geomorphologic features of the different segments of the fault to identify differences in fault activity on the segments of the fault.

\section{Geologic background}

The Sertengshan piedmont fault has been highly active since the late Quaternary (Research Group on 'Active Fault System around Ordos Massif' and State Seismological Bureau, 1988). The fault zone is composed of several parallel south-dipping normal faults, and the latest faulting has migrated toward the basin (Li, 2006; Wu et al., 1996).

Based on the geometrical distribution, tectonic activity, geomorphological features, record of paleoearthquakes and segment boundary features of the Sertengshan piedmont fault (Long et al., 2017), we divided the fault into four segments: the E-W-oriented Langshankou (Dongwugai-Wayaotan) and Hongqicun (Dahoudian-Wubulangkou) segments and the NW-SE-oriented Kuoluebulong (WubulangkouWayaotan) and Dashetai (Wayaotan-Tailiang) segments (Fig. 1).

The Langshankou segment is $75 \mathrm{~km}$ long in the E-W direction and is composed of left-stepping, obliquely arranged faults in the
Langshankou area, a linear fault in the Hulesitai area, and rightstepping, obliquely arranged faults in the Wujiahe area. This segment terminates at a southerly mountain spur in Dahoudian. The Hongqicun segment is $25 \mathrm{~km}$ long in the E-W direction and consists of rightstepping, obliquely arranged short subfractures. The boundary between the Langshankou and Hongqicun segments is the southerly Dahoudian mountain spur, which is a bedrock bulge that forms a permanent segment boundary. The Kuoluebulong segment is $45 \mathrm{~km}$ long in the NW-SE direction and is composed of several mostly arcuate secondary faults that are linearly arranged end to end. The Dashetai segment is approximately $45 \mathrm{~km}$ long in the NW-SE direction and is composed of two right-stepping, obliquely arranged secondary faults in the Xiaoshetai area. The fault in the Dashetai area is arcuate to the NE. Between Wulancun and Tailiang, the fault is straight and oriented WNW. The SW-trending Delingshan mountain spur forms the boundary between the Kuoluebulong and Dashetai segments.

\section{Methods}

\subsection{Real-time kinematic (RTK) measuring method}

In this study, we used a Trimble R10 Global Navigation Satellite System (GNSS) instrument, which is a multi-channel, multi-band system composed of receivers, antennas and digital radio sets. We used the Beijing 54 coordinate system, transverse Mercator projection and the RTK measuring method and established a base station. To obtain relatively accurate small-scale terrain data along the fault, we collected real-time measurement data from the base station as fixed values, which made a given control point unnecessary. While the mobile station was taking measurements, the antenna was kept away from any obstructions. The antenna of the mobile station was kept vertical to prevent the loss of signal lock from affecting the measurement accuracy (He et al., 2008; Langridge et al., 2017). 


\subsection{Dating method}

We analyzed 14 OSL samples at the Key Laboratory of Crustal Dynamics, Institute of Crustal Dynamics, China Earthquake Administration, to determine the stratigraphic ages of the terraces. The middle part of each sample, which was not disturbed, was used in the analysis. We dried and ground $20 \mathrm{~g}$ of the sample to measure the $\mathrm{U}$, Th and $\mathrm{K}$ contents. We added hydrogen peroxide and hydrochloric acid to the remaining sample to remove any carbonate and organic matter. We then isolated the particles with sizes from 4 to $11 \mu \mathrm{m}$ using the hydrostatic settlement method. We treated the particle groups with fluorosilicate to obtain fine-grained quartz for further measurement. The equivalent dose (DE) of the sample was determined using a Risoe DA-20-C/D OSL auto-measuring system. The natural OSL dose was measured via the middle-grain single-aliquot regenerative-dose (SAR) method. The $\mathrm{U}$, Th and $\mathrm{K}$ contents in the environmental dose rate (D) were measured with an ELEMENT inductively coupled plasma mass spectrometer. Finally, the age of the sample was determined using the equation Age (A) = DE/D (Aitken, 1998; Lu et al., 2007; Murray and Wintle, 2000, 2003).

\subsection{Calculation of the vertical fault displacement}

The vertical displacement of a fault is calculated based on uniform strata in both the footwall and the hanging wall. Many geologic outcrops of the terraces are observable in the footwall. However, the strata that correspond to those in the outcrops are buried tens of meters below the surface. Hence, we drilled geological boreholes to observe the corresponding strata and to calculate the actual vertical displacement of the fault. The stratigraphic marker strata must be identified in both the geological boreholes in the hanging wall and the terrace outcrops on the footwall to determine the vertical displacement of the fault (Murata et al., 2001).

A stratigraphic marker stratum must have the following characteristics: (1) the stratum must have a particular lithology and sedimentary structure or an identifiable interlayer interface; (2) the stratum must be unique in the vertical borehole profile; (3) the lithology and thickness of the stratum must be horizontally constant; and (4) the stratum must be distinguishable based on distinct features. Combining stratigraphic marker strata comparisons and strata age data increases the accuracy of the fault slip rate calculation.

The height difference between the stratigraphic marker strata represents the fault displacement, assuming that the strata are horizontal. Field investigations suggest that the strata in the study area are not horizontal but rather dip slightly. We correct the displacement calculation with the equation $\mathrm{h}=(\mathrm{H}-\mathrm{L} \tan \alpha) \cos \alpha$ (Fig. 2), where $\mathrm{h}$ is the actual displacement of the fault, $\mathrm{L}$ is the distance from the terrace to the borehole, and $\alpha$ is the dip angle of the terrace strata.

In the study area, the Holocene strata are mainly composed of pluvial to alluvial deposits and have variable lithologies and thicknesses, especially along the basin margins. Multiple pluvial-alluvial fans are commonly superimposed and intersect longitudinally, and the strata dip angles vary widely. Thus, it is impossible to find comparable stratigraphic marker strata on the two walls. Therefore, we estimate the thickness of the Holocene strata in different areas of the basin based on the ages of the strata, measure the heights of the terraces relative to the tops of the boreholes, and calculate the Holocene fault displacement based on these data.

\section{Geologic and geomorphologic features of the Sertengshan piedmont fault}

The Sertengshan piedmont fault has been highly active since the late Pleistocene, and multiple stages of tectonic activity have produced multiple terraces. The $\mathrm{T} 2$ and $\mathrm{T} 3$ terraces have similar deposits composed of variegated alluvial gravels at the top and yellow-green lacustrine deposits at the bottom. Two levels of terraces formed in two stages of tectonic stability, during which the faults were not active, and the ancient lake level was stable. However, the stage of T2 terrace formation was short, so the T2 terraces are smaller than the T3 terraces. The T2 terraces were cut by faults along the front margin after their formation. The T3 terraces are accumulation terraces and have no faults on the front margin (Li, 2006; Wu et al., 1996), which is verified by the outcrops and trenches in the field. We measured 20 typical geomorphologic terrains using the RTK method and dug 3 trenches along the fault (Fig. 1) to study the geologic and geomorphologic features of the fault.

\subsection{Geological and geomorphologic features at Wujiahe}

The Wujiahe study site is located on the eastern Wujiahe segment $700 \mathrm{~m}$ west of the town of Wujiahe. We performed topographic mapping using the RTK method and dug a trench on the front edge of the T1 terrace. The 4 terrace levels at this site (Fig. 3a and b) are close to the bedrock mountain, and small-scale gullies flow through them. The $\mathrm{T} 1$ terrace is $5.5 \mathrm{~m}$ high and has a maximum slope angle of $14^{\circ}$. This constructional terrace is distributed over a small area. It was formed by Holocene tectonic activity, and its top surface is several meters wide. The trench on its front edge revealed 5 active faults that trend approximately $106^{\circ}$, and the sediments in the trench revealed interactive layers of alluvial-diluvial sandy gravel layers and sandy clay (Fig. 3c). The T2 terrace is $11.3 \mathrm{~m}$ high and has a maximum slope angle of $39^{\circ}$. The top of the terrace is a 3-m-thick alluvial-diluvial sandy gravel layer, and the bottom is a yellow-green lacustrine stratum. The top surface is approximately $400 \mathrm{~m}$ wide and is cut by gullies on both sides. The fault moved again after T2 formed and produced a secondary terrace in front of T2. The T3 terrace is $24.2 \mathrm{~m}$ high and has a maximum slope angle of $36^{\circ}$. The top of the terrace is a 2 -m-thick alluvial-diluvial sandy gravel layer, and the bottom is a lacustrine stratum. The top surface of T3 is $200 \mathrm{~m}$ wide. No fault exists in front of this terrace. Both $\mathrm{T} 2$ and $\mathrm{T} 3$ formed when the Jilantai-Hetao Megalake withdrew. The T4 terrace is $34 \mathrm{~m}$ high and has a maximum slope angle of $41^{\circ}$. It is a pedestal terrace, and the top of the terrace is composed of a 2-m-thick alluvial-diluvial sandy gravel layer (Fig. 3d).

\subsection{Geologic and geomorphologic features at Liguigedan}

The Liguigedan study site is located in the middle of the Hongqicun segment and on the west bank of the Liguigedan River. We performed topographic mapping using the RTK method. This site features 4 terrace levels (Fig. 4a); the terraces on the west side are located approximately $1.7 \mathrm{~km}$ from the bedrock mountain, and the terraces on the east side are located approximately $400 \mathrm{~m}$ from the bedrock mountain. The terraces at the Liguigedan site have an arc-shaped distribution (Fig. 4b). The T1 terrace is $3.3 \mathrm{~m}$ high and has a maximum slope angle of $25^{\circ}$. This constructional terrace is distributed over a small area and is primarily composed of Holocene alluvial-diluvial sandy gravel layers. The T2 terrace is $11.7 \mathrm{~m}$ high and has a maximum slope angle of $46^{\circ}$. It is widely distributed, and the top surface is several kilometers wide. The top of the terrace is a 3-4-m-thick alluvial-diluvial sandy gravel layer, and the bottom is lacustrine strata (Fig. 4d). The T3 terrace is approximately $22.4 \mathrm{~m}$ high and has a maximum slope angle of $44^{\circ}$. The top of this pedestal terrace is composed of a 2-m-thick alluvialdiluvial sandy gravel layer, and the bottom is lacustrine strata. The fault moved again after T2 formed, which produced a secondary terrace in front of T2. The T4 terrace is $34 \mathrm{~m}$ high and has a maximum slope angle of $20^{\circ}$. This pedestal terrace has bedrock at the bottom (Fig. 4c).

\subsection{Geologic and geomorphologic features at Wubulangkou}

The Wubulangkou study site is located in the middle of the fault. We performed topographic mapping using the RTK method on the east 


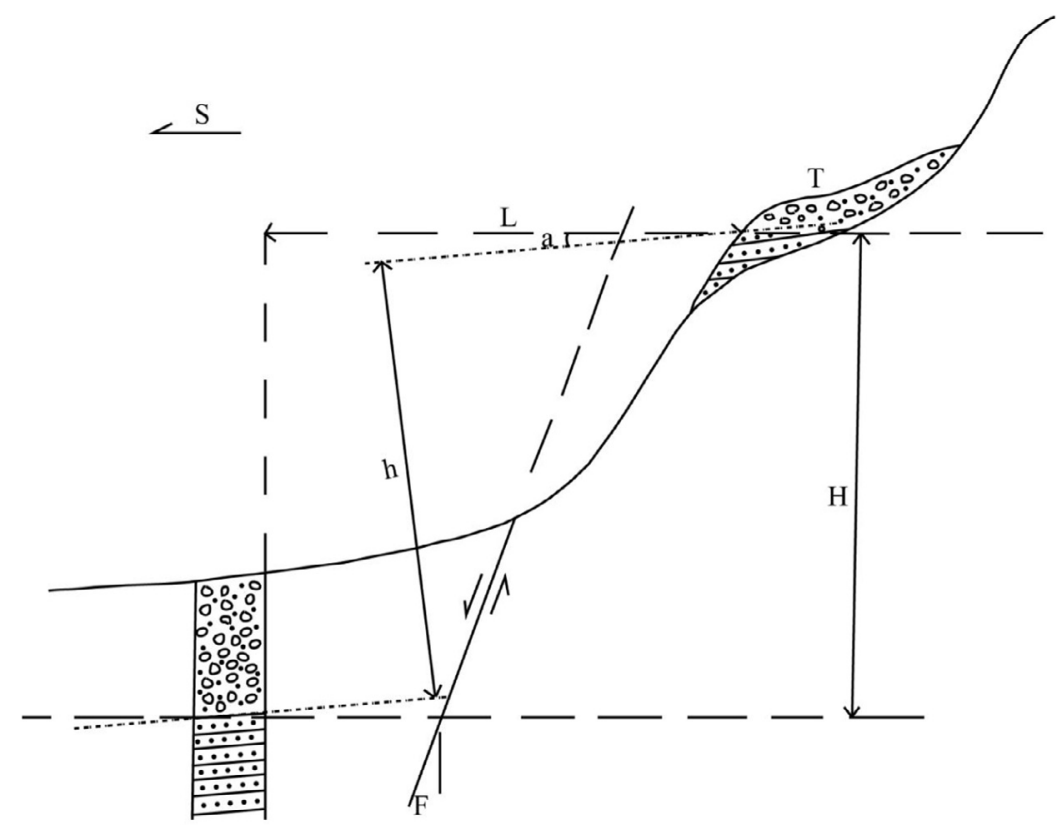

Fig. 2. Sketch map of the calculation and calibration of the vertical displacement of a fault.

bank of the Wubulangkou River and dug a trench at the front edge of the lowest terrace. The site is located approximately $4.5 \mathrm{~km}$ from the bedrock mountain. This site features 3 terrace levels (Fig. 5a). The tops of the three terraces are composed of alluvial-diluvial sandy gravel layers, and the bottoms are yellow-green lacustrine strata (Fig. 5b). The trench dug on the front edge of the lowest terrace revealed that the top is composed of alluvial-diluvial sandy gravel layers and sandy clay and that the bottom is composed of yellow-green lacustrine strata. There are seven faults in the trench profile; four dip to the south, and three dip to the north, which represent antithetic normal faults (Fig. 5c). The layers revealed by the trench show that the lowest terrace is the T2 terrace, not the T1 terrace, which disappeared because of frequent human activity at this site. The widespread T3 terrace is $32.5 \mathrm{~m}$ high and has a maximum slope angle of $46^{\circ}$. The fault moved several times after T3 formed, which produced $2 \mathrm{~T} 2$ terraces that are $10.5 \mathrm{~m}$ and $3 \mathrm{~m}$ high (Fig. 5d). The T3 and $2 \mathrm{~T} 2$ terraces are located at the front margin of the alluvial-diluvial fan, far from the bedrock mountain. The sediments are thick and loose, and the fault bifurcates into two secondary faults at this site (Long et al., 2017). Consequently, one fault movement event might produce two parallel fault scarps. The considerable fault activity since the formation of $\mathrm{T} 2$ has elevated this terrace.

\subsection{Geologic and geomorphologic features at Dashetai}

The Dashetai study site in the middle of the Dashetai segment is located $4 \mathrm{~km}$ north of the town of Dashetai. The two terrace levels feature a broad top terrace surface that is approximately $5 \mathrm{~km}$ wide south of the bedrock mountain (Fig. 6a). T1 is $5.2 \mathrm{~m}$ high and has a maximum slope angle of $35^{\circ}$. The trench dug on the front margin of T1 revealed three faults and alluvial-diluvial sandy gravel layers that indicate that the terrace formed in the Holocene. The T2 terrace is $6.6 \mathrm{~m}$ higher than $\mathrm{T} 1$ and has a maximum slope angle of $35^{\circ}$. The top of $\mathrm{T} 2$ is composed of a 3-m-thick alluvial-diluvial sandy gravel layer, and the bottom is yellow-green lacustrine strata. T2 is a pedestal terrace, and its top surface is tens of kilometers wide (Fig. 6d).

\section{Vertical slip displacements and rates of the Sertengshan piedmont fault}

\subsection{Stratigraphic ages of the Sertengshan piedmont}

We collected 14 OSL samples to determine the stratigraphic ages of the Sertengshan piedmont. Some of the sampling locations are shown in Fig. 1, and the results are listed in Table 1.

The sediments in the terraces of the Sertengshan piedmont mainly consist of alluvial-diluvial sandy gravel layers and yellow-green lacustrine strata. The dating results show that the top of the yellow-green lacustrine strata has an age of approximately $70.0 \mathrm{ka}$ (Fig. 7b). These results correspond to the age of $71.90 \pm 7.34 \mathrm{ka}$ obtained for the top of the lacustrine strata in borehole HTS4 (Chen et al., 2008a). The sandy gravel layers above the lacustrine strata in $\mathrm{T} 3$ are approximately $0.5 \mathrm{~m}$ thick and have ages of approximately 50-70 ka (Table 1). In T2, the layers above the lacustrine strata have ages of approximately 20-40 ka. For example, the age of the medium- and fine-grained sand layer in T2 northeast of the town of Dashetai is $22.42 \pm 2.56 \mathrm{ka}$ (Fig. 7d). T1 mainly consists of sandy gravel layers and sandy clay with ages of approximately $10 \mathrm{ka}$. For example, the age of the sandy clay in T1 northeast of the town of Wujiahe is $9.29 \pm 1.11 \mathrm{ka}$, and the two ages obtained for the sandy gravel layers in T1 northeast of Dongquanzi are $8.32 \pm 0.96 \mathrm{ka}$ and $9.79 \pm 1.44 \mathrm{ka}$ (Fig. $7 \mathrm{c}$ ). Based on the field observations and the characteristics of the stratigraphic marker strata, we selected the top layer of yellow-green lacustrine sediments, which was observed in both the terraces and the boreholes, as the stratigraphic marker stratum because it is distinguishable and unique in the vertical profile. The fluvial and lacustrine sediments were deposited continuously in the basin and controlled by the Sertengshan piedmont fault on the north margin of the basin since the late Pleistocene. The strata are stable and consistent in the basin, and the stratigraphic ages from borehole QK3 are complete and reasonable. Therefore, we use the dating results from borehole QK3 (Liu et al., 2014) to identify the stratigraphic marker stratum in the hanging wall. We use the displacement of the top layer of the yellow-green lacustrine strata to calculate the vertical slip rates of the Sertengshan piedmont fault since the late Pleistocene, and we use the thickness of the Holocene series and the heights of $\mathrm{T} 1$ to calculate the vertical slip rates of the Sertengshan piedmont fault during the Holocene. 


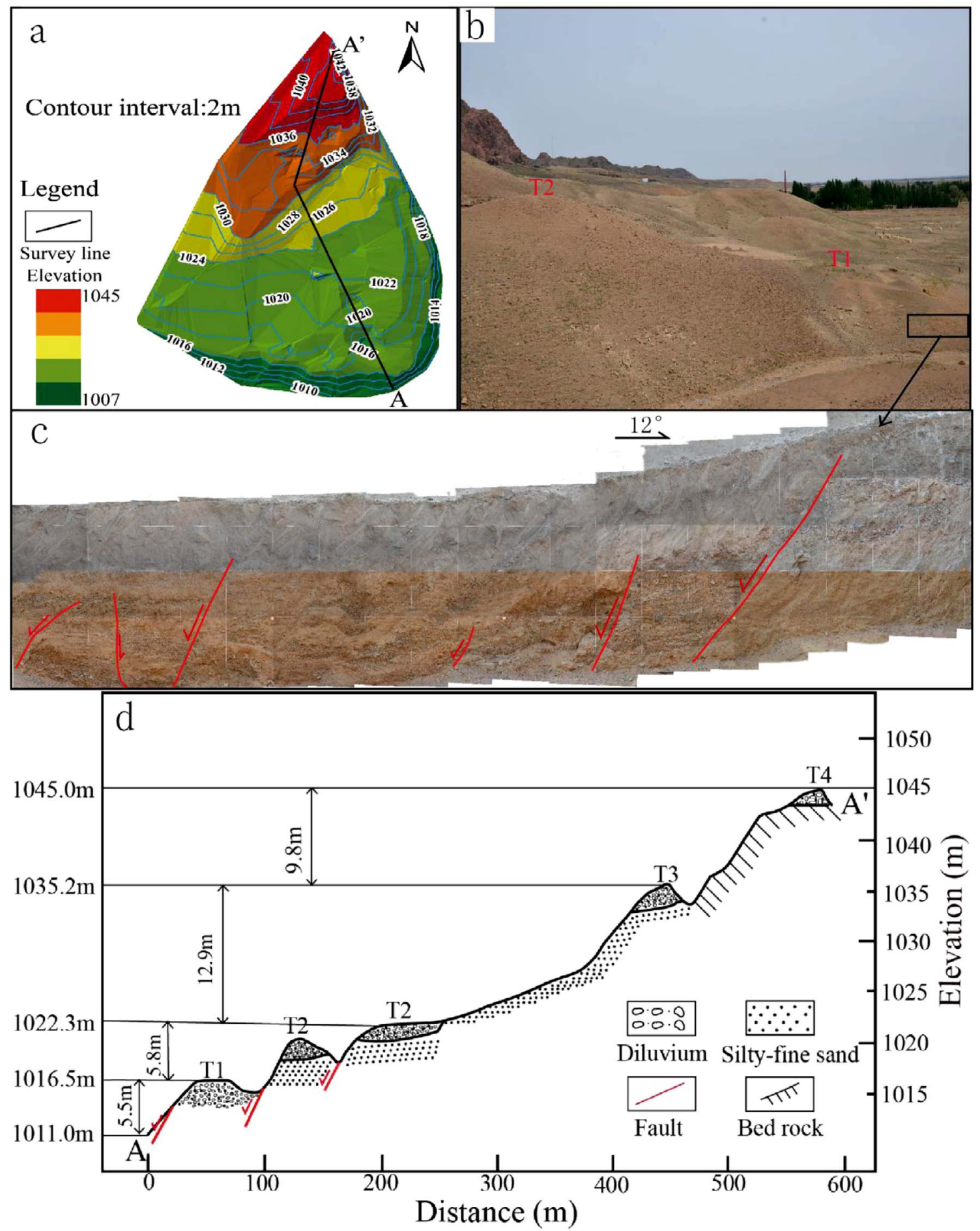

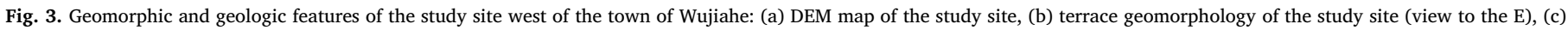
western wall of the trench at the study site and (d) profile of survey line AA'.

\subsection{Vertical displacements of the Sertengshan piedmont fault}

The multi-phase activity of the Sertengshan piedmont fault produced multiple terrace levels on the footwall. The heights of the terraces represent the vertical uplift of the footwall in different periods. Using laser rangefinders, we measured 203 terrace sites to summarize the terrace heights (i.e., the differences between the horizontal level of the basin and the tops of the terraces). We obtained three measurements at each site and calculated the mean value. The highest terraces, $\mathrm{T} 4$, are pedestal terraces that formed in the early late Pleistocene and are not helpful in calculating the vertical slip rate of the fault. Thus, we measured the heights of the TI, T2 and T3 terraces.

The terrace heights measured at 203 points are shown in Fig. 8, and the dating ages are shown in Table 1 . We define the levels of the terraces on different segments of the fault based on the terrace heights and the terrace deposits. The T1 terraces are several meters to $10 \mathrm{~m}$ high and are composed of variegated alluvial gravels. Several faults are present on the front margin of the T1 terraces. The T2 terraces are $10 \mathrm{~m}$ to more than $20 \mathrm{~m}$ high and are composed of $0.2-2$-m-thick variegated alluvial gravels at the top and yellow-green lacustrine deposits at the 


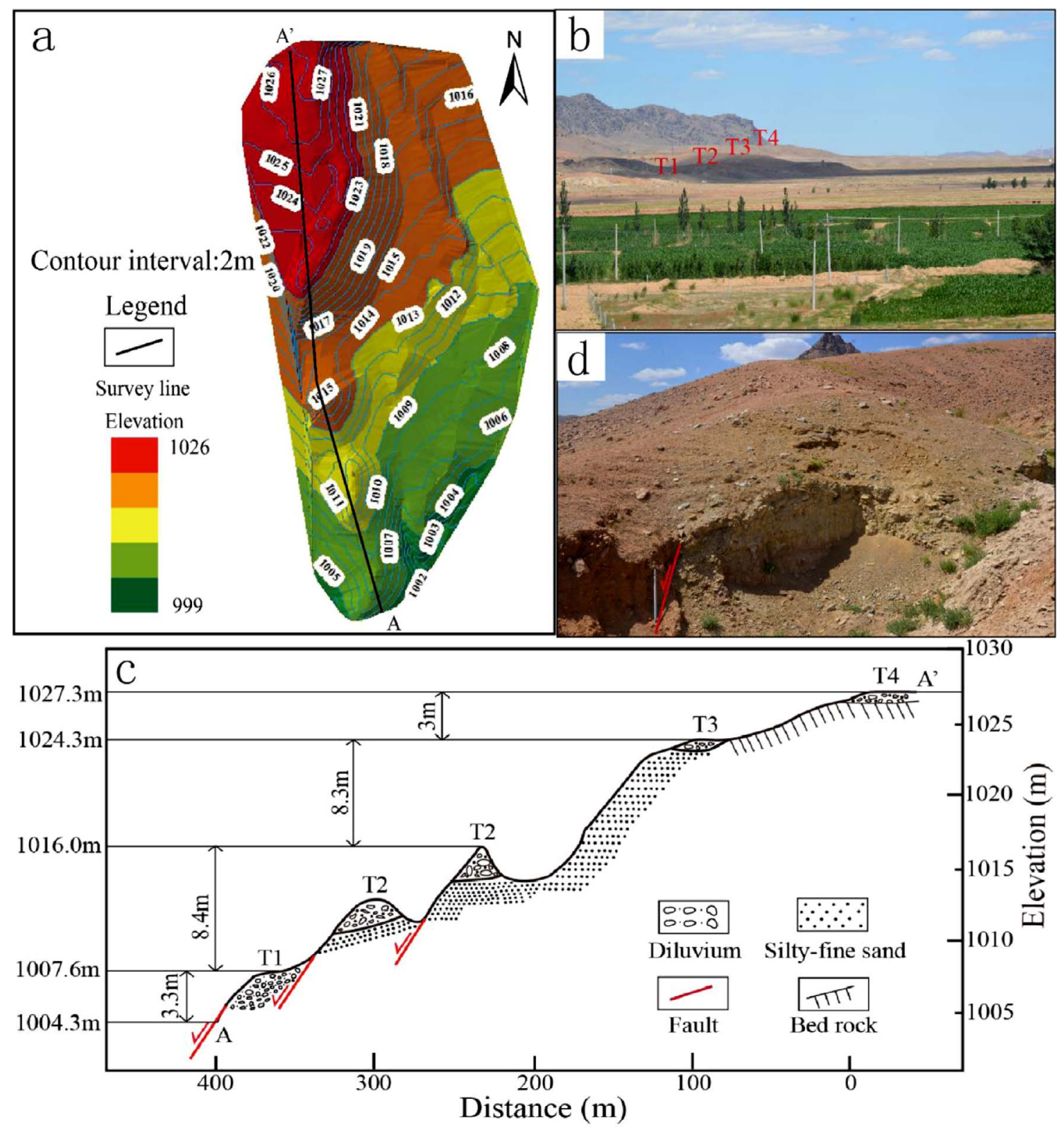

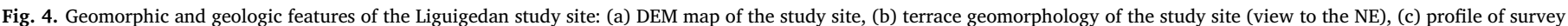
line $\mathrm{AA}^{\prime}$, (d) geological outcrop of the study site (view to the NW).

bottom. Several faults are present on the front margin of the T2 terraces. The T3 terraces are more than $20 \mathrm{~m}$ to more than $30 \mathrm{~m}$ high and contain similar deposits as the T2 terraces. There are no faults on the front margin of the T3 terraces. The results shown in Fig. 8 suggest that the mean heights of T1, T2 and T3 are $6.8 \mathrm{~m}, 15.1 \mathrm{~m}$ and $24.1 \mathrm{~m}$, respectively. Three terraces are present west of Wayaotan, whereas two terraces are present east of Wayaotan. The Wujiahe and Hongqicun segments feature relatively low T1 heights but relatively high T3 heights. The Kuoluebulong segment has higher T1 heights but lower T3 heights. The Dashetai segment has lower T1 heights and lacks T3 terraces. The Sertengshan piedmont fault is a typical normal fault that controlled the basin formation and produced terraces on the northern margin of the basin. It produced higher terraces and more terrace levels along the active segments and lower terraces and fewer terrace levels along the less active segments. Because the terrace levels and heights along different segments represent different degrees of fault activity, we conclude that the Wujiahe and Hongqicun segments have been highly active since the terraces formed, the Kuoluebulong segment has been less active, and the Dashetai segment has been the least active.

\subsection{Vertical subsidence displacements of the Sertengshan piedmont fault}

We collected 10 geological boreholes in the basin near the fault to analyze the vertical subsidence of the hanging wall (Fig. 1). The 10 boreholes and a combined borehole section are shown in Fig. 9. We describe the lithologies of boreholes ZK3 and ZK7 in Tables 2 and 3, respectively. No age data are available from these boreholes. However, borehole QK3 has a complete age data series and is very close to borehole VI-3. The wellhead elevations of boreholes QK3 and VI-3 are the same, and the stratigraphic marker stratum (i.e., the top of the lacustrine strata) is at the same elevation in both boreholes. Thus, we believe that the two boreholes contain the same sedimentary sequence, and we use the age data from QK3 as the VI-3 age data series.

We estimated the depositional environment based on the color of the strata and the sediment particle size. We then divided the strata into different sedimentary units based on the depositional environment and made stratigraphic correlations between the boreholes by comparing the units with the bottom elevation of the late Pleistocene series. The combined borehole section shows that the Holocene strata mainly 

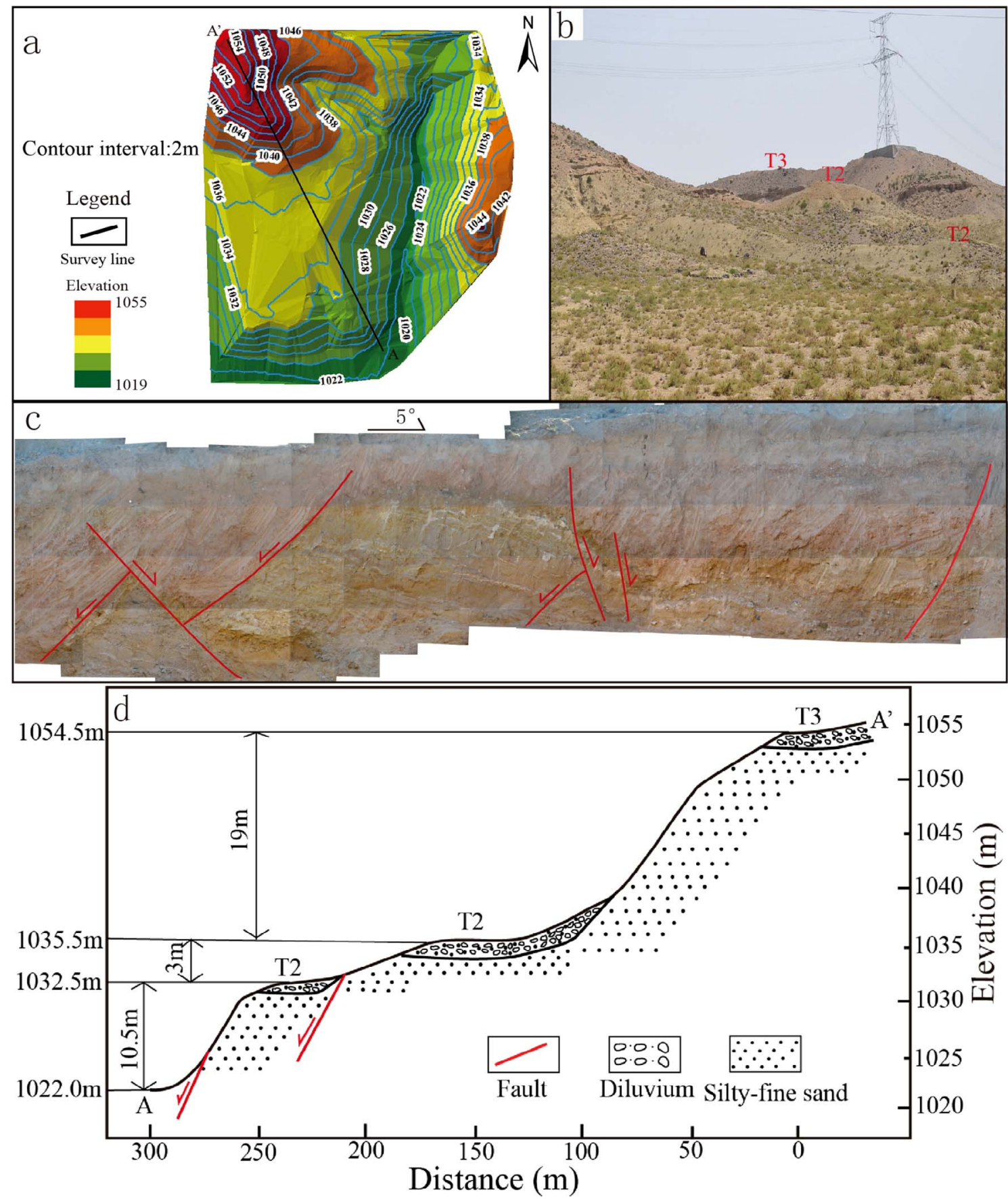

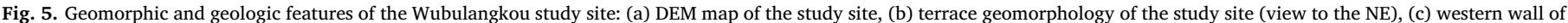
the trench at the study site and (d) profile of survey line $\mathrm{AA}^{\prime}$.

consist of sandy gravel and clayey sand layers. The Holocene strata in boreholes VII-1 and VIII-1 are mainly fine sand layers and clayey sand layers, which indicate a stable depositional environment. The deposits younger than $65 \mathrm{ka}$ in boreholes VI-1, H125 and H141 are all sandy gravel layers, which indicate considerable fault activity and a depositional environment dominated by strong fluvial activity. The Holocene strata in boreholes ZH18, ZK3, ZK6 and ZK7 are fine sand layers with occasional sandy gravel layers, which indicate a depositional environment that alternated between strong fluvial activity and static water. The Jilantai-Hetao Megalake in the late Pleistocene occupied the entire Hetao basin on the northern margin of the Ordos block (Chen et al., 2008a, 2008b). The combined borehole section shows that the top of the lacustrine strata has an age of approximately $65 \mathrm{ka}$, which means that the withdrawal of the Jilantai-Hetao Megalake began at approxi- mately $65 \mathrm{ka}$. A large amount of evidence suggests that the JilantaiHetao Megalake emerged after 100-120 ka, occupied the entire Hetao basin until $65 \mathrm{ka}$ and then disappeared rapidly (Chen et al., 2008b; Li, 2006). Fig. 9 demonstrates that the sediments in the boreholes younger than 65 ka are mainly sandy gravels and clay, which indicate a constant alluvium and diluvium sedimentary environment. After the withdrawal of the lake, the depositional environment transitioned to that present during the Holocene. According to the depositional history of the basin and paleoclimatic data, the withdrawal of the Jilantai-Hetao Megalake was affected by the fault activity (Li, 2006). The uneven fault activity along different segments of the fault resulted in differences in the wellhead elevations and deposit thicknesses in the combined borehole section. The post-65 ka deposits are thick near the town of Wujiahe and thinner to the west and east. 


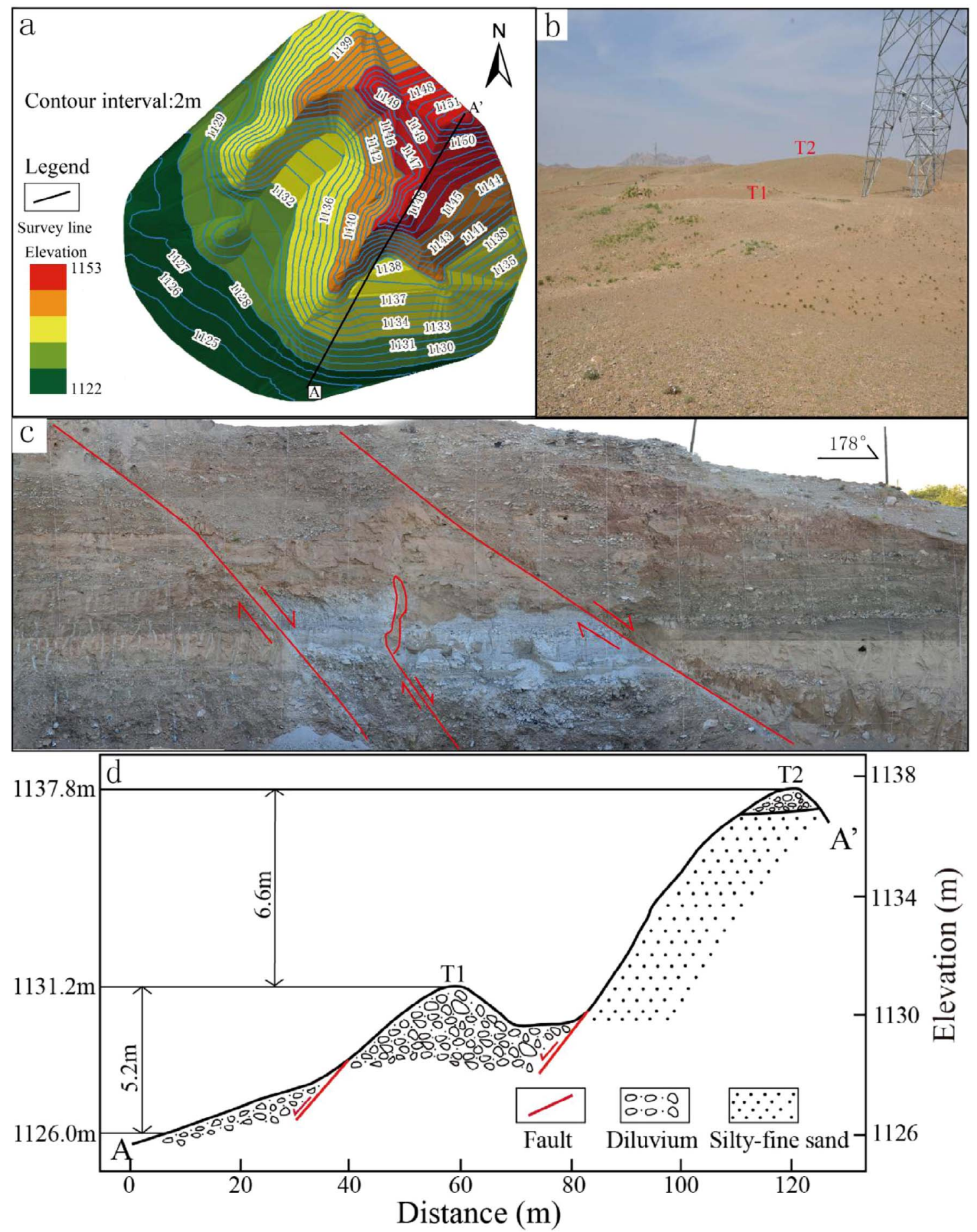

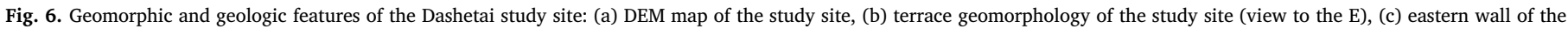
Wulancun trench at the study site and (d) profile of survey line $\mathrm{AA}^{\prime}$.

\subsection{Vertical slip rates of the Sertengshan piedmont fault}

We use the nine geological boreholes near the fault and the adjacent terrace heights measured via the RTK method to calculate the vertical displacements along the fault (Fig. 10). The elevation of ZK is the elevation (relative to sea level) of the top of the lacustrine strata, which formed at approximately $65.0 \pm 3.2 \mathrm{ka}$. The lacustrine strata were exposed to surface environments after the withdrawal of the JilantaiHetao Megalake. The horizontal layers of the lacustrine strata near the fault were inclined toward the basin due to the faulting. We measured the attitudes of numerous strata from the boreholes and found that most of the lacustrine layers had dip angles between $1^{\circ}$ and $2^{\circ}$. Therefore, we corrected the displacements with the equation $\mathrm{h}=(\mathrm{H}-\mathrm{L} \tan \alpha) \cos , \alpha$ based on the distance from the terrace to the borehole and the dip angle of the top layer of the lacustrine strata (Table 4). We assume that the lacustrine strata have a nearly horizontal dip angle of $1-2^{\circ}$.

Table 4 shows the vertical displacements of the fault at different sites since $65.0 \pm 3.2 \mathrm{ka}$, which are $113.7 \mathrm{~m}$ at Fanrong, $94.2 \mathrm{~m}$ at Fengyu, $102.6 \mathrm{~m}$ at Tongyilong, $117.4 \mathrm{~m}$ at Wujiahe, $108.2 \mathrm{~m}$ at Hongqicun, $63.5 \mathrm{~m}$ at Wubulangkou, $57.6 \mathrm{~m}$ at Delingshan, $61.1 \mathrm{~m}$ at 
Table 1

Ages of the Sertengshan piedmont terraces.

\begin{tabular}{|c|c|c|c|c|c|c|c|c|c|}
\hline Sample location & Method & $\mathrm{U}(\mu \mathrm{g} / \mathrm{g})$ & Th $(\mu g / g)$ & $\mathrm{K}(\%)$ & Water content $(\%)$ & Environmental dose rate $(\mathrm{Gy} / \mathrm{ka})$ & Equivalent dose (Gy) & Terrace & Age (ka) \\
\hline Northern Wujiahe & OSL & 2.31 & 10.2 & 1.84 & 2.04 & 3.99 & $37.13 \pm 2.41$ & $\mathrm{~T} 1$ & $9.29 \pm 1.11$ \\
\hline Northern Dongquanzi & OSL & 3.27 & 10.7 & 2.23 & 3.91 & 4.78 & $37.72 \pm 2.27$ & $\mathrm{~T} 1$ & $8.32 \pm 0.96$ \\
\hline Northern Dongquanzi & OSL & 2.28 & 9.86 & 2.08 & 0.52 & 4.20 & $41.09 \pm 4.46$ & $\mathrm{~T} 1$ & $9.79 \pm 1.44$ \\
\hline Northern Xishuidao & OSL & 1.82 & 9.96 & 1.88 & 1.41 & 3.84 & $44.25 \pm 1.58$ & $\mathrm{~T} 1$ & $11.54 \pm 1.23$ \\
\hline Northern Xishuiquan & OSL & 1.12 & 5.12 & 2.38 & 0.54 & 3.59 & $80.39 \pm 4.46$ & $\mathrm{~T} 2$ & $22.42 \pm 2.56$ \\
\hline Eastern Fanrong & OSL & 1.83 & 9.29 & 2.23 & 0.34 & 4.13 & $136.32 \pm 15.44$ & $\mathrm{~T} 2$ & $33.01 \pm 1.99$ \\
\hline Western Langshankou & OSL & 2.82 & 10.1 & 2.23 & 4.59 & 4.55 & $108.16 \pm 11.39$ & $\mathrm{~T} 2$ & $23.97 \pm 3.45$ \\
\hline Northern Mabozi & OSL & 1.54 & 11.4 & 1.79 & 0.38 & 3.79 & $165.13 \pm 16.93$ & $\mathrm{~T} 2$ & $23.25 \pm 2.88$ \\
\hline Western Alagaitu & OSL & 1.18 & 6.04 & 2.19 & 1.73 & 3.51 & $184.78 \pm 9.32$ & $\mathrm{~T} 3$ & $52.69 \pm 5.90$ \\
\hline Western Liushuquanzi & OSL & 2.08 & 8.21 & 2.41 & 0.66 & 4.30 & $309.82 \pm 28.31$ & $\mathrm{~T} 3$ & $72.05 \pm 9.76$ \\
\hline Northern Shuiquan & OSL & 1.4 & 5.21 & 2.28 & 0.63 & 3.60 & $217.40 \pm 18.61$ & T3 & $60.34 \pm 7.94$ \\
\hline Eastern Dashetai & OSL & 1.65 & 11.4 & 2.28 & 12.2 & 4.01 & $286.35 \pm 26.71$ & $\mathrm{~T} 3$ & $71.38 \pm 9.76$ \\
\hline Northern Bafenzi & OSL & 2.08 & 9.07 & 1.76 & 0.69 & 3.71 & $247.50 \pm 16.58$ & $\mathrm{~T} 3$ & $66.72 \pm 8.03$ \\
\hline Wulan & OSL & 1.97 & 9.46 & 1.91 & 0.84 & 3.87 & $307.39 \pm 21.29$ & $\mathrm{~T} 3$ & $79.50 \pm 9.67$ \\
\hline
\end{tabular}

Xishuiquan, and $48.2 \mathrm{~m}$ at Kuoluebulong. The corresponding mean vertical slip rates since $65.0 \pm 3.2 \mathrm{ka}$ are $1.75 \mathrm{~mm} / \mathrm{a}, 1.45 \mathrm{~mm} / \mathrm{a}$, $1.58 \mathrm{~mm} / \mathrm{a}, \quad 1.81 \mathrm{~mm} / \mathrm{a}, \quad 1.66 \mathrm{~mm} / \mathrm{a}, \quad 0.98 \mathrm{~mm} / \mathrm{a}, \quad 0.89 \mathrm{~mm} / \mathrm{a}$, $0.94 \mathrm{~mm} / \mathrm{a}$, and $0.74 \mathrm{~mm} / \mathrm{a}$, respectively. The vertical slip rates are highest in the middle of the fault and lower to the west and east. Additionally, the rates correspond to the terrace geomorphology. The Sertengshan piedmont fault intersects the Langshan piedmont fault at Fanrong in a right-lateral stepover. The Langshan piedmont fault has also been an active normal fault since the late Pleistocene. Fanrong is affected by both the Sertengshan piedmont fault and the Langshan piedmont fault. Therefore, the unexpectedly high rate at Fanrong is related to the Langshan fault to the west.

Boreholes VIII-1, H125 and H141 did not reveal the complete Holocene series. However, the bottom of the clay layer in VI-3 has an age of $12 \mathrm{ka}$, and the observed portion of the Holocene series is $15 \mathrm{~m}$ thick. Two geological boreholes $10 \mathrm{~km}$ and $15 \mathrm{~km}$ south of Shuiquan yielded Holocene series thicknesses of $14 \mathrm{~m}$ and $8.5 \mathrm{~m}$, respectively (Yang et al., 2002). The Holocene series are mainly fluvial and pluvial deposits, and the thicknesses are likely greater near the fault. Thus, Table 4 provides the maximum vertical displacements during the Holocene: $24.6 \mathrm{~m}$ at Fanrong, $20.6 \mathrm{~m}$ at Fengyu, $10.5 \mathrm{~m}$ at Wubulangkou, $25.8 \mathrm{~m}$ at Delingshan, $17.0 \mathrm{~m}$ at Xishuiquan and $24.8 \mathrm{~m}$ at Kuoluebulong. The mean vertical slip rates of the fault during the Holocene are $2.05 \mathrm{~mm} / \mathrm{a}, \quad 1.72 \mathrm{~mm} / \mathrm{a}, \quad 0.86 \mathrm{~mm} / \mathrm{a}, \quad 2.13 \mathrm{~mm} / \mathrm{a}$, $1.42 \mathrm{~mm} / \mathrm{a}$ and $2.07 \mathrm{~mm} / \mathrm{a}$, respectively. We speculate that the Holocene series is $15 \mathrm{~m}, 18 \mathrm{~m}$ and $16 \mathrm{~m}$ thick in the Tongyilong, Wujiahe and Hongqicun areas, respectively, based on the vertical slip rates since the late Pleistocene. Therefore, the mean vertical slip rates during the Holocene in Tongyilong, Wujiahe and Hongqicun are $2.03 \mathrm{~mm} / \mathrm{a}$, $2.28 \mathrm{~mm} / \mathrm{a}$ and $1.86 \mathrm{~mm} / \mathrm{a}$, respectively, based on the thicknesses of the Holocene series and the terrace heights.

\section{Discussion}

The Ordos block has a long evolutionary history and contains a hard cratonic basement (Xu et al., 1994; Zhang, 1989; Zhao, 2002). Graben

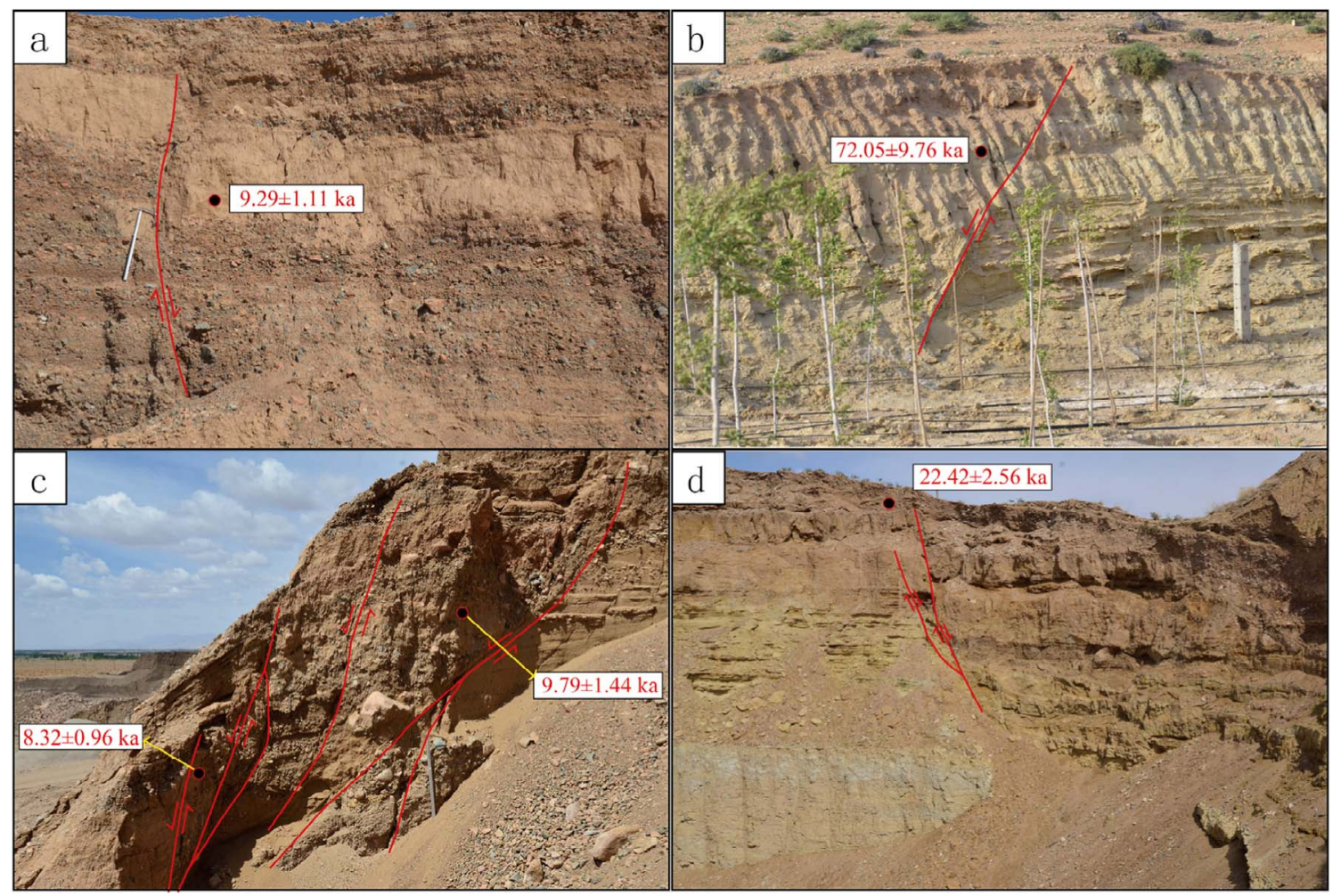

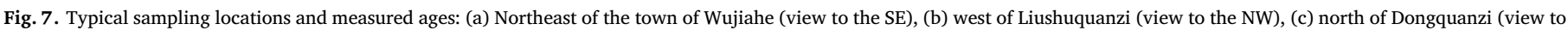
the W) and (d) northeast of the town of Dashetai (view to the SE). 


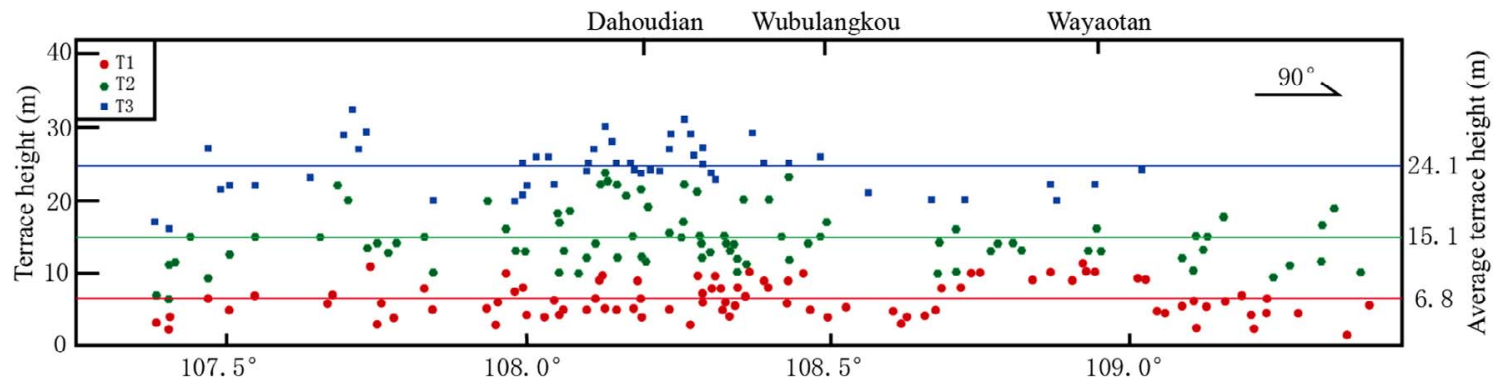

Fig. 8. Distribution of terrace heights on the Sertengshan piedmont.

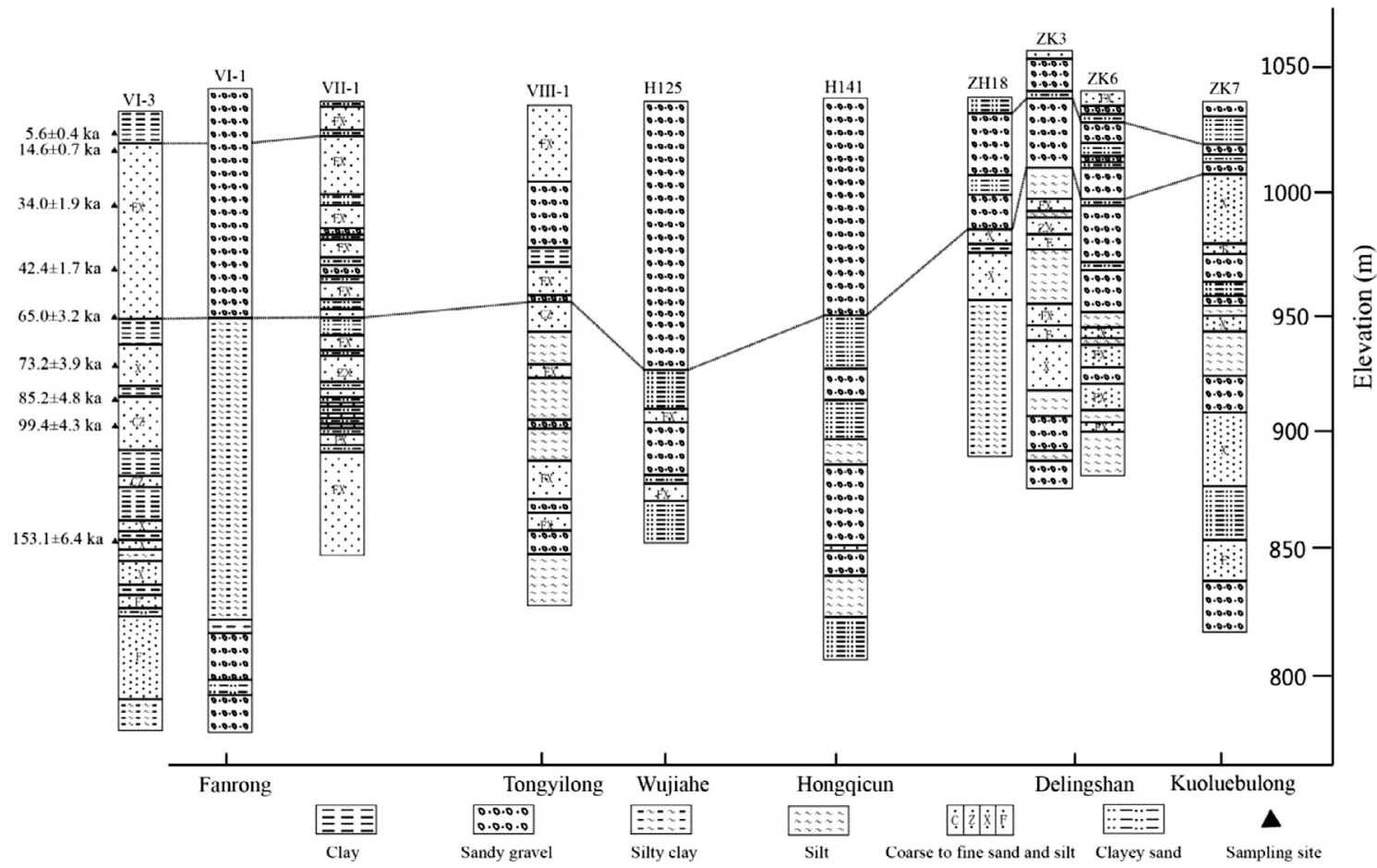

Fig. 9. Sketch of the combined borehole section.

Table 2

Lithologies in borehole ZK3.

\begin{tabular}{|c|c|c|c|}
\hline Stratum serial number & $\begin{array}{l}\text { Depth of the stratum bottom } \\
\text { (m) }\end{array}$ & Thickness (m) & Lithologic description \\
\hline 1 & 3.70 & 3.70 & Silt, yellow and brown, loose, poor water permeability, low water content \\
\hline 2 & 18.90 & 15.20 & Sandy gravel, red to green-gray, loose. Gravel diameter 5-15 mm, maximum gravel diameter $20-50 \mathrm{~mm}$ \\
\hline 3 & 19.60 & 0.70 & Brownish-yellow sandy clay, $25 \%$ fine sand and medium-coarse sand \\
\hline 4 & 48.05 & 28.35 & $\begin{array}{l}\text { Red to yellow sandy gravel, maximum gravel diameter } 30-70 \mathrm{~mm}, 40 \% \text { gravel, } 25 \% \text { medium-coarse } \\
\text { sand, sandy clay in the middle }\end{array}$ \\
\hline 5 & 54.80 & 6.75 & Grayish-green silty clay, partial cementation, $35 \%$ silt, occasional calcium nodules \\
\hline 6 & 67.50 & 9.70 & Gray silty fine sand, loose, good water permeability \\
\hline 7 & 69.40 & 1.90 & Greenish-gray silty sand, poor water permeability, chemical odor \\
\hline 8 & 77.40 & 8.00 & Grayish-green intermediate fine sand, loose, good water permeability \\
\hline 9 & 82.90 & 5.50 & Grayish-green silt, partial cementation \\
\hline 10 & 105.30 & 22.40 & Grayish-green silty clay, weak stratification, strong chemical odor \\
\hline 11 & 108.00 & 2.70 & Grayish-green silty fine sand, loose \\
\hline 12 & 109.30 & 1.30 & Grayish-green compact silty sand \\
\hline 13 & 141.80 & 32.50 & $\begin{array}{l}\text { Greenish-gray find sand, very loose, containing gravels with diameters of 5-10 mm, good water } \\
\text { permeability }\end{array}$ \\
\hline 14 & 153.70 & 11.90 & Greenish-gray silt, good stratification, chemical odor \\
\hline 15 & 167.60 & 12.90 & $\begin{array}{l}\text { Grayish-green sandy gravel, very loose, with gravel 5-10 } \mathrm{mm} \text { in diameter, maximum gravel diameter } \\
150 \mathrm{~mm}\end{array}$ \\
\hline 16 & 172.00 & 4.40 & Grayish-green silt \\
\hline 17 & 188.40 & 16.40 & $\begin{array}{l}\text { Grayish-green sandy gravel normally } 5-10 \mathrm{~mm} \text { in diameter, maximum gravel diameter } 70 \mathrm{~mm} \text {, good } \\
\text { water permeability }\end{array}$ \\
\hline
\end{tabular}


Table 3

Lithologies in borehole ZK7.

\begin{tabular}{|c|c|c|c|}
\hline Stratum serial number & $\begin{array}{l}\text { Depth of the stratum bottom } \\
\text { (m) }\end{array}$ & Thickness (m) & Lithologic description \\
\hline 1 & 5.95 & 5.95 & $\begin{array}{l}\text { Grayish-yellow sandy gravel, } 40-50 \% \text { gravel, gravel normally } 2-8 \mathrm{~mm} \text { in diameter, clayey sandy soil in } \\
\text { the upper } 0.7 \mathrm{~m}\end{array}$ \\
\hline 2 & 18.50 & 12.55 & $\begin{array}{l}\text { Grayish-black and yellow sandy clay containing mica and shells, silty sand and fine sand in the bottom } \\
\text { layer }\end{array}$ \\
\hline 3 & 22.59 & 4.09 & Yellowish-green sandy gravel with gravel normally $2-5 \mathrm{~mm}$ in diameter \\
\hline 4 & 25.00 & 2.41 & Brown and grayish-black sandy clay occasionally containing gravely and medium-fine sand \\
\hline 5 & 31.03 & 6.03 & Greenish-gray sandy gravel, loose, containing a silt layer, good water permeability \\
\hline 6 & 59.68 & 28.65 & Greenish-gray fine sand, occasionally containing medium sand and gravel \\
\hline 7 & 64.71 & 5.03 & Grayish-black silty sand, loose, well sorted \\
\hline 8 & 75.00 & 10.29 & $\begin{array}{l}\text { Grayish-white sand gravel, loose, with gravel normally } 2-8 \mathrm{~mm} \text { in diameter, sub-rounded, containing } \\
\text { calcareous sands and sandy clay }\end{array}$ \\
\hline 9 & 86.00 & 11.00 & Grayish-black and grayish-green clayey silty sand and some silty fine sand \\
\hline 10 & 90.00 & 4.00 & Gray silt, poor stratification, containing gravel and silty sand at the bottom \\
\hline 11 & 93.52 & 3.52 & $\begin{array}{l}\text { Greenish-gray fine sand, loose, primarily quartz grains, containing a thin calcareous medium-coarse } \\
\text { sand layer at the bottom }\end{array}$ \\
\hline 12 & 115.19 & 21.67 & Grayish-black compact silt with horizontal bedding, some silty sand \\
\hline 13 & 129.00 & 13.81 & $\begin{array}{l}\text { Sandy gravel, gray at the top and yellowish-green at the bottom, loose, with gravel normally } 2-6 \mathrm{~mm} \text { in } \\
\text { diameter }\end{array}$ \\
\hline 14 & 159.66 & 30.66 & $\begin{array}{l}\text { Yellowish-green and brown fine sand, loose, partial stratification, occasionally containing medium sand } \\
\text { and gravel }\end{array}$ \\
\hline 15 & 183.05 & 23.39 & Brownish-yellow silty sand, occasionally containing medium sand and gravel \\
\hline 16 & 200.11 & 16.06 & $\begin{array}{l}\text { Yellowish-green silty sands, loose, containing fine sand and some clay as well as medium sand and gravel } \\
\text { at the bottom }\end{array}$ \\
\hline 17 & 241.84 & 41.73 & $\begin{array}{l}\text { Brownish-yellow sandy gravel, loose, with gravel normally } 3-5 \mathrm{~mm} \text { in diameter containing } 20-30 \% \\
\text { medium sand }\end{array}$ \\
\hline
\end{tabular}

faulting has occurred frequently around the Ordos block (Deng and You, 1985; Jiang et al., 2014, 2016; Ran et al., 2003). The grabens around the block have different structural settings, orientations, formation ages and fault kinematics. The Shanxi fault belt and the Yinchuan-Jilantai fault belt to the east and west of the Ordos block, respectively, exhibit right-lateral shear extension, and the Weihe fault belt and Hetao fault belt to the south and north of the Ordos block, respectively, exhibit left-lateral shear extension. Numerous arcuate faults have formed due to intense compression and left-lateral slip to the southwest of the block. The Hetao fault belt is oriented E-W and is controlled by the Langshan, Sertengshan, Wulashan and Daqingshan faults from west to the east (Fig. 11).

The vertical uplift rates are calculated from the uplift of the footwall, and the absolute vertical slip rates are calculated by combining the vertical uplift of the footwall with the vertical settlement of the hanging wall. Normally, the absolute vertical slip rate of the fault is twice the vertical uplift rate of the northern margin fault zone of the Hetao basin. We compare the absolute vertical slip rates with two times the vertical uplift rates of the faults. The maximum Holocene vertical slip rate of the Daqingshan fault is $1.72 \mathrm{~mm} / \mathrm{a}$ (Wu et al., 1996), and the

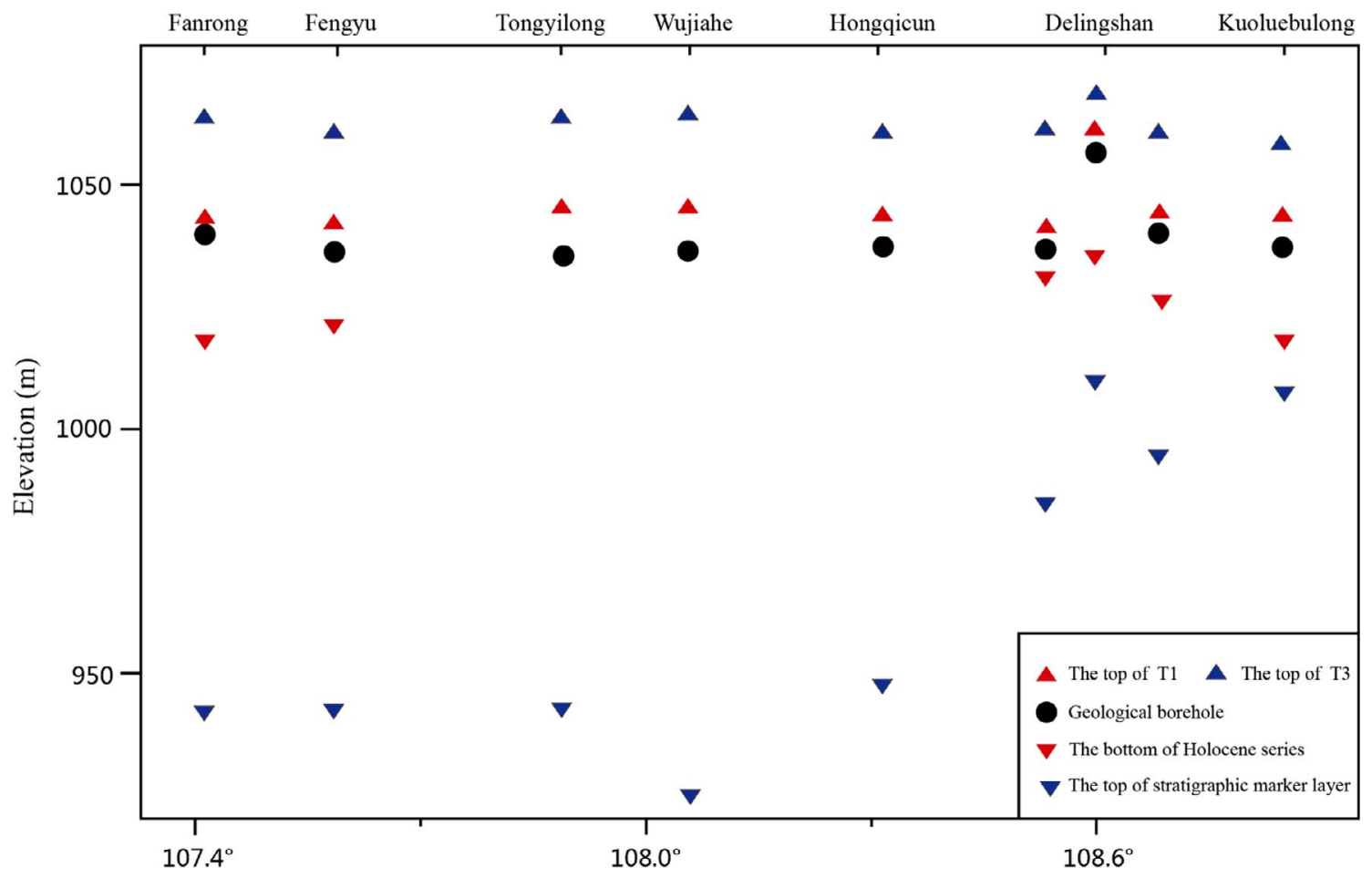

Fig. 10. Elevation distribution of the stratigraphic marker strata in the terraces and the geological boreholes. 
Table 4

Vertical displacements on the Sertengshan piedmont fault

\begin{tabular}{|c|c|c|c|c|c|c|c|c|c|}
\hline Location & Fanrong & Fengyu & Tongyilong & Wujiahe & Hongqicun & Wubulangkou & $\begin{array}{l}\text { Northwest of } \\
\text { Delingshan }\end{array}$ & $\begin{array}{l}\text { West } \\
\text { Shuiquan }\end{array}$ & Kuoluebulong \\
\hline Borehole & VI-1 & VII-1 & VIII-1 & H125 & $\mathrm{H} 141$ & ZH18 & ZK3 & ZK6 & ZK7 \\
\hline T3 elevation (m) & 1062.5 & 1060.4 & 1063.0 & 1064.0 & 1060.0 & 1061.0 & 1068.0 & 1060.0 & 1058.0 \\
\hline $\mathrm{T} 1$ elevation $(\mathrm{m})$ & 1042.5 & 1042.0 & 1045.0 & 1045.5 & 1043.3 & 1041.0 & 1061.0 & 1043.2 & 1043.0 \\
\hline Wellhead elevation (m) & 1040.6 & 1036.2 & 1035.6 & 1036.1 & 1037.0 & 1037.3 & 1055.7 & 1039.8 & 1036.4 \\
\hline $\begin{array}{l}\text { Elevation of the Holocene series in the footwall } \\
\text { (m) }\end{array}$ & 1017.9 & 1021.4 & & & & 1030.5 & 1035.2 & 1026.2 & 1018.2 \\
\hline $\begin{array}{l}\text { Vertical displacement of the Holocene series } \\
\text { (m) }\end{array}$ & 24.6 & 20.6 & & & & 10.5 & 25.8 & 17.0 & 24.8 \\
\hline Elevation of the top of the lacustrine strata (m) & 941.9 & 942.3 & 942.6 & 925.0 & 947.6 & 984.1 & 1009.0 & 994.5 & 1007.2 \\
\hline $\begin{array}{l}\text { Displacement of the stratigraphic marker layer } \\
\text { since } 65 \mathrm{ka}(\mathrm{m})\end{array}$ & 120.6 & 118.1 & 120.4 & 139.0 & 112.4 & 76.9 & 59.0 & 65.5 & 50.8 \\
\hline Vertical displacement after correction & 113.7 & 94.2 & 102.6 & 117.4 & 108.2 & 63.5 & 57.6 & 61.1 & 48.2 \\
\hline
\end{tabular}

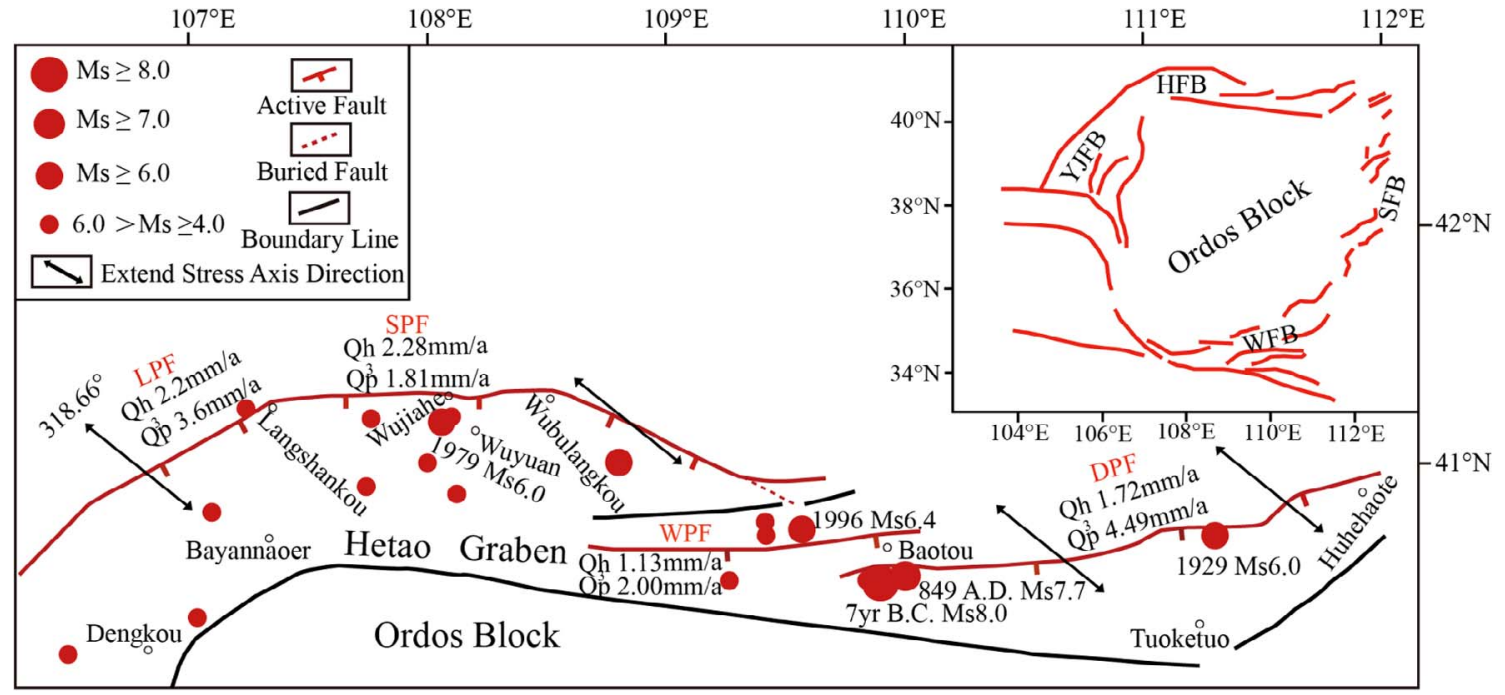

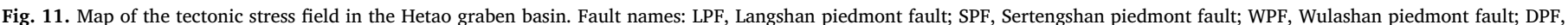
Daqingshan piedmont fault.

maximum vertical slip rate of the Wulashan fault is $1.13 \mathrm{~mm} / \mathrm{a}$ (Chen, 2002). The maximum vertical slip rate of the Sertengshan fault is $1.27 \mathrm{~mm} / \mathrm{a}$ (Wu et al., 1996), and the maximum vertical slip rate of the Langshan fault is $2.2 \mathrm{~mm} / \mathrm{a}$ (Wu et al., 1996). Based on the results of previous studies, the Daqingshan and Langshan faults have higher vertical slip rates than the Sertengshan and Wulashan faults.

The maximum vertical slip rate of the Daqingshan fault since the late Pleistocene (25 ka) is $4.49 \mathrm{~mm} / \mathrm{a}$ (Wu et al., 1996), and the maximum vertical uplift rate of the footwall of the Wulashan fault since $30-40 \mathrm{ka}$ is $2.0 \mathrm{~mm} / \mathrm{a}$ (Ma et al., 1998). The maximum vertical slip rate of the Sertengshan fault since $22-27 \mathrm{ka}$ is $1.83 \mathrm{~mm} / \mathrm{a}$ (Chen et al., 2003a; Yang et al., 2002, 2003), and the maximum vertical uplift rate of the footwall of the Langshan fault since $30-40 \mathrm{ka}$ is $3.6 \mathrm{~mm} / \mathrm{a}$ (Wu et al., 1996). Based on the results of previous studies, we conclude that the vertical slip rates of the Daqingshan and Langshan faults have been higher than those of the Sertengshan and Wulashan faults since the last stage of the late Pleistocene.

Previous researchers have held different views on the tectonic dynamics of the peripheral fault zones in the Ordos block. Two views are popular. The first view suggests that the left-lateral slip of the Haiyuan fault and the northern margin zone of the Qinling Mountains on the northeastern margin of the Tibetan Plateau have affected the formation and evolution of the basins in northern China since the late Cenozoic (Gaudemer et al., 1995; Li et al., 2013; Peltzer et al., 1985; Tapponnier et al., 1982, 1986; Wang et al., 2014; Zhang et al., 1999). This view considers the India-Eurasian collision to be the main driver of the formation and evolution of the basins in northern China since the late Cenozoic. The second view holds that the basins in northern China and the peripheral fault zones of the Ordos block are affected by the subduction of the western Pacific plate beneath the Eurasian plate and that the basins are in fact back-arc basins (Northrup et al., 1995; Tian et al., 1992; Uyeda and Kanamori, 1979). Previous researchers have studied the tectonic stress field of the peripheral fault zones of the Ordos block and have concluded that the tectonic stress on the northern margin of the Ordos block is extensional in the NW-SE direction (Deng et al., 1999; Fan et al., 2003; Qu et al., 2017; Xie et al., 2000, 2004; Xue and Yan, 1984; Zhang et al., 2006; Zhao et al., 2016). The Hetao graben basin is controlled by NE-SW compression and NW-SE extension. The principal compressive stress axis and the tensile stress axis are approximately horizontal, and the tensile stress axis has an orientation of $138.66^{\circ}$.

The faults along the northern margin of the Hetao graben basin are in the same tectonic stress field but have a different strike direction. Thus, the tensile stress affects these faults differently. When the angle between the extensional stress axis and the fault strike is $90^{\circ}$, the dipslip component of the extensional stress and the dip-slip rate are the greatest. When the angle between the extensional stress axis and the fault strike is lower, the dip-slip component of the extensional stress decreases, and the strike-slip component of the extensional stress increases, which increases the strike-slip rate. As shown in Table 5, the angle between the extensional stress axis and the fault strike (i.e., the clockwise angle from the fault strike to the extensional stress axis) is highest for the Langshan fault, second highest for the Daqingshan fault, and lowest for the East Sertengshan fault. Consequently, the vertical 
Table 5

Relationship between the extensional stress axis and the fault strike along the northern margin of the Hetao graben basin

\begin{tabular}{|c|c|c|c|c|c|}
\hline Faults & Langshan fault & West Sertengshan fault & East Sertengshan fault & Wulashan fault & Daqingshan fault \\
\hline Fault strike & Approximately $55^{\circ}$ & Approximately $90^{\circ}$ & Approximately $120^{\circ}$ & Approximately $90^{\circ}$ & Approximately $75^{\circ}$ \\
\hline Angle between the extensional stress axis and fault strike & $83^{\circ}$ & $48^{\circ}$ & $18^{\circ}$ & $48^{\circ}$ & $63^{\circ}$ \\
\hline
\end{tabular}

slip rates are highest along the Langshan fault, second highest along the Daqingshan fault and lowest along the East Sertengshan fault. In addition, the angles between the extensional stress axis and the strikes of these faults are less than $90^{\circ}$, and all of these faults consequently exhibit left-lateral strike-slip. Thus, the Hetao graben basin is in a leftlateral extensional environment.

This analysis demonstrates that the vertical slip rates are greater than the strike-slip rates on these faults along the northern margin of the Hetao basin. Of these faults, the Langshan and Daqingshan faults have the highest vertical slip rates, and the Sertengshan and Wulashan faults have lower vertical slip rates. All the faults have low strike-slip rates. Faults with higher slip rates are more likely to produce earthquakes, especially at sites of stress concentrations. Historical data demonstrate that the Hetao graben basin is a seismically active area, especially near the northern margin faults. The 1979 Wuyuan 6.0 earthquake occurred on the Sertengshan fault, and the 1996 Baotou 6.4 earthquake occurred on the East Wulashan fault (Wen, 2014). The Baotou 8.0 earthquake in 7 B.C. and the Baotou 7.7 earthquake in 849 CE occurred on the West Daqingshan fault (Nie, 2013; Nie et al., 2010, 2011). Based on the epicenters of earthquakes with magnitudes greater than 5 in the instrumental seismic record, the area east of the Wulashan fault and west of the Daqingshan fault has produced the most earthquakes. This area between the Wulashan and Daqingshan faults is a pull-apart structure, and the two faults have high vertical slip rates. Therefore, this area readily accumulates seismic stress and represents a potential earthquake site in the future.

The Langshankou and Wubulangkou sites on the Sertengshan fault are located in areas where the orientation of the fault changes, and therefore, they are sites of seismic stress accumulation. Thus, these areas may experience earthquakes in the future. However, the slip rates at these sites are low, and the potential earthquakes would likely not be devastating. The Wujiahe site has the highest vertical slip rate along the Setengshan fault and has experienced modern small shocks. Consequently, it is a potential earthquake location. However, the geometric configuration of the Wujiahe site is too smooth and simple to accumulate seismic stress, and the potential earthquakes would be smaller than those in the Baotou area. The Sertengshan and Wulashan faults are aligned in a right-stepping en echelon configuration. The Wulashan Mountains block the left-lateral slip movement of the Sertengshan fault. Therefore, the eastern end of the Sertengshan fault accumulates seismic stress gradually, and the likelihood of earthquakes occurring in the area is high. Therefore, the Langshankou, Wujiahe, and Wubulangkou faults, the eastern end of the Sertengshan fault and the Baotou area of the Daqingshan fault are at risk of potential earthquakes in the future.

\section{Conclusions}

(1) Our study suggests that the maximum vertical slip rates of the Sertengshan fault are $1.81 \mathrm{~mm} / \mathrm{a}$ since $65 \mathrm{ka}$ and $2.28 \mathrm{~mm} / \mathrm{a}$ during the Holocene. The slip rate is highest in the Wujiahe segment and lower to the west and east. The slip rate results indicate that the number of levels and the heights of the terraces along the Sertengshan piedmont fault correspond to the fault activity. This finding indicates that the fault activity has varied over time. The vertical slip rates of the faults in the Holocene are higher than those since the last stage of the late Pleistocene.

(2) The analysis of the vertical component of the principal tensile stress shows that the vertical slip rates of the Daqingshan and Langshan faults are higher than those of the Sertengshan and Wulashan faults. The strike-slip rates of these faults are low because the strike-slip component of the principal tensile stress is small, and the rightstepping fault distribution limits stress propagation. The Wulashan Mountains block the left-lateral strike-slip movement of the Sertengshan fault, whereas the Daqingshan fault has a higher rate of left-lateral strike-slip because it is not completely blocked.

(3) Based on the analysis of the distributions of historical and modern earthquake epicenters and the seismogenic structure, we believe that the Langshankou, Wujiahe, and Wubulangkou areas, the eastern end of the Sertengshan fault and the Baotou area of the Daqingshan fault are at high risk of future earthquakes. The Baotou area has a high risk of devastating earthquakes.

\section{Acknowledgments}

This work is supported by the 1:50,000 geological mapping of the Sertengshan piedmont fault (201408023), a research grant from the Institute of Crustal Dynamics, China Earthquake Administration (ZDJ2016-11) and the National Science Foundation of China (No. 41602221).

The OSL samples were analyzed by Dr. Zhao-Junxiang at the Key Laboratory of Crustal Dynamics, Institute of Crustal Dynamics, China Earthquake Administration. We thank the anonymous reviewers for their helpful comments on the manuscript.

\section{References}

Aitken, M.J., 1998. An Introduction to Optical Dating. Oxford University Press.

Chen, F.H., Fan, Y., Chun, X., Madsen, D.B., Oviatt, C.G., Zhao, H., Yang, L., Sun, Y., 2008a. Preliminary research on Megalake Jilantai-Hetao in the arid areas of China during the Late Quaternary. Chin. Sci. Bull. 53, 1725-1739.

Chen, F.H., Fan, Y.X., Chun, X., 2008b. Preliminary study of the "Jilantai-Hetao" Megalake in Late Quaternary. Sci. Bull. 53, 1207-1219.

Chen, L.C., 2002. Paleoearthquakes, the Law of Strong Earthquake Recurrence and Potential Sites for the Occurrence of Future Strong Earthquakes in the Hetao FaultDepression Zone. Master's Dissertation Institute of Geology, China Earthquake Administration.

Chen, L.C., Ran, Y.K., Chang, Z.P., 2003a. Characteristics of late Quaternary faulting and paleoseismic events on the east of Delingshan segment of the Seertengshan Piedmont fault. Seismol. Geol. 25, 555-565.

Chen, L.C., Ran, Y.K., Yang, X.P., 2003b. Late Quaternary activity and segmentation model of the Seertengshan Piedmont fault. Earthq. Res. China 19, 255-265.

Deng, Q.D., Cheng, S.P., Min, W., 1999. Discussion on Cenozoic tectonics and dynamics of Ordos block. J. Geomech. 5, 13-21.

Deng, Q.D., You, H.C., 1985. Mechanism structural and activity of Ordos basin. In: Institute of Geology, CEA (Ed.), Study on the Modern Crustal Movement (1). Seismological Press.

Fan, J.X., Ma, J., Diao, G.L., 2003. Contemporary tectonic stress filed around the Ordos fault block inferred from earthquake focal mechanism. Seismol. Geol. 25, 88-99.

Gaudemer, Y., Tapponnier, P., Meyer, B., Peltzer, G., Shunmin, G., Zhitai, C., Huagung, D., Cifuentes, I., 1995. Partitioning of crustal slip between linked, active faults in the eastern Qilian Shan, and evidence for a major seismic gap, the 'Tianzhu gap', on the western Haiyuan Fault, Gansu (China). Geophys. J. Int. 120, 599-645.

He, Z.T., Ma, B.Q., Tian, Q.J., Zhang, S.M., 2008. Deformation features of surface rupture of the Wenchuan earthquake (M 8.0) at the Pingtong town. Quaternary Sci. 28, 789-795.

Jiang, W.L., Han, Z.J., Zhang, J.F., Jiao, Q., 2016. Stream profile analysis, tectonic geomorphology and neotectonic activity of the Damxung-Yangbajain rift in the south Tibetan Plateau. Earth Surf. Proc. Land. 41, 1312-1326.

Jiang, W.L., Wang, X., Tian, T., Zhang, J., Wang, D., 2014. Detailed crustal structure of the North China and its implication for seismicity. J. Asian Earth Sci. 81, 53-64.

Langridge, R.M., Ries, W.F., Dolan, J.F., Schermer, E.R., Siddoway, C., 2017. Slip rate estimates and slip gradient for the Alpine Fault at Calf Paddock, Maruia River, New Zealand. NZ J. Geol. Geophys. 8, 1-16.

Li, A., Ran, Y.K., Xu, L.X., Liu, H., 2013. Paleoseismic study of the east Kalpintage fault in 
southwest Tianshan based on deformation of alluvial fans and 10Be dating. Nat. Hazards 68, 1075-1087.

Li, J.B., 2006. A Study on the Lake Forming Environment and Tectonic Activity during the Late Quaternary in the Hetao Basin, Inner Mongolia Autonomous Region. Institute of Geology, Institute of China Earthquake Administration, China.

Liu, Z., Zhao, H., Wang, C.M., 2014. OSL ages of sedimentary layers in Linhe depression since Late Pleistocene. Arid Land Geogr. 37, 439-446.

Long, J.Y., He, Z.T., Zhang, H., Ma, B.Q., 2017. The Characteristics of Structural Geomorphology and Segmentation of Sertengshan Piedmont Fault from Dahoudian to Wayaotan. Geoscience 31, 1-10.

Lu, Y.C., Wang, X.L., Wintle, A.G., 2007. A new OSL chronology for dust accumulation in the last 130,000 yr for the Chinese Loess Plateau. Quatern. Res. 67, 152-160.

Ma, B.Q., Sheng, X.Q., Zhang, S.R., 1998. Late Quaternary activities of the Wulashan Piedmont fault. In: Institute of Crustal Dynamics, China Earthquake Administration (Eds.), Crustal Tectonics and Crustal Stress (15). Seismological Press, pp. 22-27.

Murata, A., Takemura, K., Miyata, T., Lin, A.M., 2001. Quaternary vertical offset and average slip rate of the Nojima Fault on Awaji Island, Japan. Island Arc 10, 360-367.

Murray, A.S., Wintle, A.G., 2000. Luminescence dating of quartz using an improved single-aliquot regenerative-dose protocol. Radiat. Meas. 32, 57-73.

Murray, A.S., Wintle, A.G., 2003. The single aliquot regenerative dose protocol: potential for improvements in reliability. Radiat. Meas. 37, 377-381.

Nie, Z.S., 2013. Preliminary investigation on the history M8 earthquake occurred in 7BC at Baotou, Inner Mongolia. Acta Seismological Sinica 35, 584-603.

Nie, Z.S., Ren, Y., Liu, Z.M., Du, C.L., Cong, P.L., 2011. Preliminary study on seismic active faults of the Daqingshan frontal in Baotou City, Inner Mongolia. Geogr. Sci. 25, 938-957.

Nie, Z., Wu, W., Ma, B., 2010. Surface rupture of the A.D. 849 earthquake occurred to the east of Baotou city, China, and discussion on its parameters. Acta Seismol. Sin. 32, 94-107.

Northrup, C.J., Royden, L.H., Burchfiel, B.C., 1995. Motion of the Pacific plate relative to Eurasia and its potential relation to Cenozoic extension along the eastern margin of Eurasia. Geology 23, 719-722.

Peltzer, G., Tapponnier, P., Zhitao, Z., Qin, X.Z., 1985. Neogene and Quaternary faulting in and along the Qinling Shan. Nature 317, 500-505.

Qu, W., Lu, Z., Zhang, M., Zhang, Q., Wang, Q., Zhu, W., Qu, F., 2017. Crustal strain fields in the surrounding areas of the Ordos Block, central China, estimated by the leastsquares collocation technique. J. Geodyn. 106, 1-11.

Ran, Y.K., Chen, L.C., Yang, X.P., Han, Z., 2003. Recurrence characteristic of lateQuaternary strong earthquakes on the major faults along the northern border of Ordos block. Sci. China, (Ser. D): Earth Sci. 46 (2 Suppl.), 189-200.

Research Group on "Active Fault System around Ordos Massif", State Seismological Bureau, 1988. Active Fault System around Ordos Massif. Seismological Press.

Tapponnier, P., Peltzer, G., Armijo, R., 1986. On the mechanics of the collision between
Indian and Asia. Collision Tectonics: Spec. Publ. Geol, Soc. Lond, 19, 115-157.

Tapponnier, P., Peltzer, G., Le Dain, A.Y., Armijo, R., Cobbold, P., 1982. Propagating extrusion tectonics in Asia: new insights from simple experiments with plasticine. Geology 10, 611-616.

Tian, Z.Y., Han, P., Xu, K.D., 1992. The Mesozoic-Cenozoic East China rift system. Tectonophysics 208, 341-363.

Uyeda, S., Kanamori, H., 1979. Back-arc opening and the mode of subduction. J. Geophys. Res. 84, 1049-1061.

Wang, C.Y., Sandvol, E., Zhuc, L., Lou, H., Yao, Z., Luo, X., 2014. Lateral variation of crustal structure in the Ordos block and surrounding regions, North China, and its tectonic implications. Earth Planet. Sci. Lett. 387, 198-211.

Wen, X.Z., 2014. Structures of source regions of the 1970 Ms 6.0 Wuyuan earthquake and the 1996 Ms 6.4 Baotou earthquake in Inner Mongolia, China. Seismol. Geol. 36, $586-596$.

Wu, W.M., Nie, Z.S., Xu, G.L., et al., 1996. Research on the active fault of Western Segment of the Piedmont Fault of Seerteng (5). In: Institute of Geology, SSB (Ed.), Seismological Press, pp. 113-124.

Xie, F.R., Cui, X.F., Zhao, J.T., Chen, Q.C., Li, H., 2004. Regional division of the recent tectonic stress field in China and adjacent area. Chin. J. Geophys. 47, 654-662.

Xie, F.R., Su, S.B., Dou, S.Q., Zhang, S., Cui, X., 2000. Quaternary tectonic stress field in the region of Haiyuan-Liupan-shan Fault zone to Yinchuan fault depression. Seismol. Geol. 22, 139-146.

Xu, X.W., Cheng, G.L., Ma, X.Y., 1994. Rotation model and dynamics of blocks in north China and its adjacent area. Earth Sci.-J. China Univ. Geosci. 19, 129-138.

Xue, H.Y., Yan, J.Q., 1984. The contemporary crustal stress field around the Ordos block. Chin. J. Geophys. 27, 144-152.

Yang, X.P., Ran, Y.K., Hu, B., Guo, W.S., 2002. Active fault and paleoearthquakes of the Piedmont fault (Wujumengkou-Dongfeng Village) for Seerteng Mountains, Inner Mongolia. Earthq. Res. China 18, 127-140.

Yang, X.P., Ran, Y.K., Hu, B., Guo, W.S., 2003. Paleoseismic activity on Wujiahe segment of Seerteng Piedmont fault, inner Monglia. Acta Seismol. Sin. 25, 62-71.

Zhang, K., 1989. Tectonics and Resources of Ordos Faulted-Bolock. Shanxi Science and Technology Publishing House.

Zhang, Y.Q., Liao, C.Z., Shi, W., Hu, B., 2006. Neotectonic evolution of the peripheral zones of the Ordos basin and geodynamic setting. Geol. J. China Univ. 12, 285-297.

Zhang, Y., Vergely, P., Mercier, J.L., 1999. Pliocene-Quaternary faulting pattern and left slip propagation tectonics in north China. Episodes 22, 84-88.

Zhao, W.T., Hou, G.T., Haric, K.R., 2016. Two episodes of structural fractures and their stress field modeling in the Ordos Block, northern China. J. Geodyn. 97, 7-21.

Zhao, Z.Y., 2002. Tectonic characteristics of the Ordos basin and oil and gas accumulation. In: Desheng, Li (Ed.), Tectonics of Petroliferous Basins in China. Petroleum Press, pp. 410-426. 